\title{
Translation competence and the aesthetic attitude
}

\author{
Kirsten Malmkjær \\ Middlesex University, United Kingdom
}

\begin{abstract}
Teachers whose aspiration is for their students to achieve Translation Competence need an understanding of its nature and of ways to help students attain it. The notion is related to that of Natural Translation, which proposes a series of developmental stages of the interpreting ability of a bilingual infant/child. The theory claims that links established between sets of items in a bilingual's languages as the languages are acquired are exploited during a pretranslation stage from which Natural Translation develops. This is not incompatible with recent understanding of the Universal Grammar hypothesis and recent findings in the neurolinguistics of bilingualism. However, the model cannot account for non-native bilinguals' abilities to translate, nor for translation abilities developed during formal instruction. These abilities might be based on innate Interlingual Proficiency and Transfer Proficiency Potentials. I list a number of ways in which Toury has agued that these potentials may be encouraged and add a suggestion or two of my own.
\end{abstract}

Key words: translation competence, natural translation, Universal Grammar, translation pedagogy, translation and enjoyment, the aesthetic attitude

\section{Introduction}

There comes a time in the life of most disciplines when it or some of its notions appear to have reached a point of stagnation, impasse or simply general scholarly boredom. All that can be said seems to have been said, with relatively little advance or agreement. Within Transtation Studies, the notion of equivalence is sometimes eonsidered to be in this state. In such cases, it can be helpful to go back to the beginnings of scholarly research on the topic to see whether something there, at the roots, may have been overlooked, which might now seem more significant, perhaps in the light of advances in related areas of study. In this article I want to do this for a notion that seems to me to be in the danger zone, namely "translation competence". While I would not dare claim that we have not advanced in research on this notion, I refer the reader to Shreve (2002) and Pym (2003) for expressions of some frustration with the state of the art. I shall also argue for a renaming of the phenomenon, which I will address from two perspectives, the theoretical and the pedagogical. I base my 
study on two quotations, one by an eminent linguist and one by an eminent translation scholar. The first quotation is from Brown (1996: 1):

A teacher who proposes to teach something to a student should have a clear grasp of what is to be taught. This means not only having a good grasp of what is to be taught in a particular class, but also a view of how that part of the subject relates to the whole subject area.

The relationships between parts of subjects, and between parts of subjects and whole subjects, are represented in theories. A theory of $\mathrm{X}$ is a set of beliefs that ideally have preferred status among a community of scholars who have the wider community's sanction and trust; their preferred beliefs thus ideally become preferred by the wider community too. The set of preferred beliefs is thought of as internally coherent. Indeed, a new hypothesis is typically tested for coherence with other preferred beliefs within the larger theory.

The perceived coherence of belief systems is extremely important both practically and pedagogically. If we did not believe in a coherent universe we would be unable to reason from past through present to future and to understand simple everyday causality, let alone more complex relations between cause and effect; problem-solving activities would be hit-and-miss events; learning would be unthinking habit formation; and teaching would be impossible.

The interdisciplinarity of Translation Studies can be counterproductive of intra-disciplinary theoretical coherence, because one of the consequences of interdisciplinarity is a tendency to adopt and adapt, selectively, concepts and terms from a variety of disciplines. Intra-theoretical coherence is difficult to ensure in such circumstances, because those who borrow from discipline Y may not be expert in cofeeder discipline $\mathrm{Z}$, and scholar A may have a different understanding of disciplines $\mathrm{Y}$ and $\mathrm{Z}$ than scholar B has. Obviously, this may affect the translation teacher's ability to grasp their subject in the way Brown thinks essential. Besides, interdisciplinarity complicates the drawing of boundaries around disciplines and tends to make the area across which coherence needs to be established demandingly vast. However, as Toury (1984: 188) notes:

if translation pedagogy does not wish to renounce all claims to pedagogical validity and go on operating on more or less intuitive grounds [...] it has hardly any choice but set up, if only tentatively, its own conceptions and models of the initial and terminal "translation competence" 
and of the interdependencies between them, and establish on their basis the most efficient methods of approximating a student from the former to the latter position.

In other words, assuming that we desire pedagogical validity in translation teaching, we need to know how "translation competence" begins, develops and ends, and this requires us to have a good grasp of what "translation competence" is. In the following section I shall reflect on this notion and on the relationship between it and its cousin, linguistic competence, from which it derives in at least one of its earliest manifestations, albeit in rather few of its later manifestations.

\section{Competence}

Anyone with even a fleeting acquaintance with linguistics will tend to be reminded by relate the term "competence" toof linguistic competence as understood within theoretical linguistics, even though the link between this notion and that employed by most translation scholars is tenuous. A notable exception to this general tendency is Harris and Sherwood's (1978: 155) description of "translating [including interpreting] done in everyday circumstances by people who have had no special training for it", as "an innate verbal skill" which is "coextensive with bilingualism". Harris and Sherwood call this "natural translation" and explicitly relate it to "Chomsky's sense of 'competence"” (1978: 160).

\section{Natural Translation}

On the basis of case studies of untrained people of ages ranging from birth to eighteen years, and with a variety of European language pairs (as well as mathematical symbolism), but mainly on the basis of their reading of the famous case studies of childhood bilingualism by Ronjat (1913) and Leopold (1949), Harris and Sherwood present what they think of as "stages that a young natural translator goes through" (1978: 155), namely (1978: 167):

1. Pretranslation observed by Ronjat in his French-German bilingual son, from the time the child was one year and two months old. Pretranslation involves automatic production of both realizations (one in each language) of one concept, as exemplified by the following examples from Ronjat (cit. Harris and Sherwood 1078: 166): 
Father: Dis merci (French: "say thank you”)

Child: Danke (German: “thank you”)

Mother: Was hat Papa im Mund (German: "what has father in his mouth?")

Child: Pfeife (German: "pipe”)

Father: Qu'est-ce que c'est que ça? (French: "what is it that it is?”)

Child: Pipe (French: “pipe”).

According to Ronjat, in the first case, the child responds by reflex in German because he is most often asked to say "thank you" in that language. In the second case, the languages of inquiry simply trigger two linguistic realisations of the one concept. Harris and Sherwood (1978: 166) call this a "bilingual response", and in neither case, according to Ronjat as well as to Harris and Sherwood, is translation involved. The child at this stage (co-extensive with the one-word stage of monolingual acquisition) can also be observed spontaneously rehearsing word pairs: "oeil/Auge" ("eye"); "Schiff/Bateau" ("boat"), a playful, enjoyable use of the two languages which persists later (Harris and Sherwood 1978: 166).

2. Interpersonal autotranslation means translation of one's own utterance for the benefit of others (1978: 165). This is concurrent with the later stages of pretranslation, and was observed by Ronjat from when his son was aged one year and nine months. It is preceded by a stage during which the child autotranslates for itself; this stage can clearly be considered similar in nature and motivation to the playfulness with single words just mentioned.

3. Transduction is defined as "communication in which the translator acts as an intermediary between two other people" (1978: 165). This was observed by Leopold in his daughter when she was three years and three months old. It is clearly what most people think of as translation.

Harris and Sherwood (1978: 167) speculate about the relationship between these stages and monolingual language development and about which of the notions 
of innateness then prevalent in developmental psycholinguistics is relevant to their study: A weak sense of "a specialized predisposition in children to learn how to speak from the language they hear in their environment"; or the strong sense of "an inherited 'theory' of language ('universal grammar') which enables the child to speak sooner and more grammatically than can be accounted for by its chronology [i.e. age]" (1978: $168)^{1}$. In spite of the above mentioned parallel which Harris and Sherwood (1978: 160) draw between Natural Translation and "Chomsky's sense of 'competence", they now opt for the weak sense of innateness, because they believe that only this will allow them to speculate about what may be required for the special disposition to engage in Natural Translation over and above what is required for the acquisition of the languages as such, and they list the following as potential features (1978: 168-9):

i) the pleasure that young children derive from translating

ii) a bilingual mental lexicon

iii) a language-independent semantic store

iv) an ability to conserve meaning across languages

Clearly, Harris and Sherwood's findings amount to no more than rather weakly based hypotheses about the developmental stages that a natural translator goes through, since each stage is exemplified by only one or a very few individuals speaking different language pairs. Nevertheless, the issues that they address remain central for a coherent theory of translation competence and for translation pedagogy, and we can take Harris and Sherwood's proposed stages as an hypothesis to be further tested, meanwhile seeing how well it is relatable (i) to the more carefully developed, contemporary hypothesis of Universal Grammar (UG), (ii) to recent findings from the neurolinguistics of bilingualism, and (iii) to recent explorations in the area of translation competence.

Were the stages proposed found to be supported, certain advantages would immediately accrue, especially with regard to the first stage: A spontaneous pretranslation stage lets us off the difficult theoretical hook of accounting for first steps; if translation links are established between languages as they are acquired, we have a good basis for translation activity proper. 
In addition, innately endowed pretranslation would provide a rationale for cognitively determined translation universals (Malmkjær, forthcoming), such as the under-representation in translations of features of the target language that are not shared by the source language, compared to their representation in original writing in the (target) language (Tirkkonen-Condit, 2004). Tirkkonen-Condit suggests that the phenomenon of under-representation in translation of features unique to the target language arises because such features are under-represented in a translator's mental lexicon while he or she is translating. Nothing in the source text is likely to trigger them. The idea of pretranslation strengthens this supposition, because it suggests that the lack of opportunity for linking to the other language during acquisition may result in a permanently weak activation (see below) of unique items, compared to terms that have counterparts in the other language.

\section{Linguistic Competence}

Within theoretical linguistics, the notion of competence is the notion of a native speaker's knowledge of their language, which is sharply distinguished from their performance, "the actual use of language in concrete situations" (Chomsky 1965: 4). Speakers' abilities to do things with words in actuality depend heavily on aspects of context (see Austin 1962; Hymes 1971; 1972a; 1972b) which lie way beyond the area that is theorizable from the Chomskyan view of language as primarily part of the natural (as opposed to the social) world, and of Competence as an unconscious mental state reached at the end of a process of biological growth. The development takes place by means of interaction between (i) linguistic input data received by the language-acquiring individual and (ii) the default or initial state of the language faculty, which contains innate knowledge called Universal Grammar (UG) (Wearing 2006: 341). UG includes (i) "a set of innately endowed grammatical principles which determine how grammatical operations apply in natural language grammars"; and (ii) "a set of grammatical parameters which impose severe restrictions on the range of grammatical variation permitted in natural languages (perhaps limiting variation to 
binary choices)" (Radford 2004: 11). In addition, there is "a set of semantic primitives, out of which specific word meanings are constructed" (Carr 2006: 333).

The steady state that is Competence is characteristic of every normal adult native speaker of a given language, variations in performance being exactly that: Performance features, influenced by aspects of the social world, including e.g. teaching and learning. Competence is internal to each single individual; it is an Ilanguage. It is not the shared, social, supra-individual entity that Saussure's (1916) langue is often understood to be (Lyons 1996: 15), and which, for Chomsky, who of course does not deny its existence, is E-language. I-language is not primarily designed for use in communication, according to Chomsky ${ }^{1}$, but for thinking (Carr 2006: 332); it is an instrument of cognitive growth (Brown 1996: 3).

Relatively little has been said in terms of this model of language about Formatted: Font: $12 \mathrm{pt}$ bilingualism and bilingual acquisition, but there is a clear tendency not to distinguish these from monolingualism and monolingual acquisition in any fundamental way, and to think of multilingualism as an inevitable consequence of the complexities of natural language, and of the lack of clear boundaries between languages, and between languages, dialects and registers (Chomsky 2000: 169):

Even to speak of Peter as having the I-language L is a severe simplification; the state of any person's faculty of language is some jumble of systems that is no more likely to yield theoretical understanding than most other complex phenomena of the natural world. Peter is said to be multilingual when the differences among his languages happen to interest us for one or another reason; from another point of view, everyone is multiply multilingual.

This view is compatible with one of the most prevalent current understandings of Bilingual Language Acquisition, according to which children who are addressed in two languages from birth "have two first languages: A and Alpha" (De Houwer 2006: 780). The evidence for this is that "from the onset of even somewhat intelligible speech, children raised with two languages from birth mostly produce utterances that can be related to just one of either of their input languages". They do not mix the two systems randomly, but are able to switch easily and contextually appropriately "between unilingual utterances in language A, unilingual utterances in language Alpha, and mixed utterances" (De Houwer 2006: 784). Therefore, they must from early on be "able to determine that the huge range of variation in speech sounds that they are exposed to can be categorized according to two main categories, two main 
ways of speaking" (De Houwer 2006: 781). The issues of how a bilingual's languages are organised and how their uses are controlled are addressed within the neurolinguistics of bilingualism, to which I shall now turn.

\section{The neurolinguistics of bilingualism}

The Chomskyan view discussed above is in accord with findings in the neurolinguistics of bilingualism as documented in Paradis (1985, 1987a, 2004; see also Ahlsén 2006 and Fabbro 1999). Paradis's understanding of bilingualism, like Chomsky's, assumes no categorical difference between it and monolingualism. A bilingual has "two subsets of neural connections, one for each language, within the same cognitive system, namely, the language system" (Paradis 2004: 110), and (Paradis 2004: 112):

awareness of language membership is a product of metalinguistic knowledge. In online processing, language awareness is of the same nature and as unconscious as the process that allows a unilingual speaker to understand (or select) the appropriate word in a given context. The process of selecting a Russian word by a Latvian-Russian bilingual person is the same as the process that allows a unilingual Russian speaker to select among the indefinite, almost unlimited, possibilities for encoding a given message.

Both processes involve relating the selected item to a single, language-independent conceptual component (Paradis 2004: 200):

the conceptual component of verbal communication is not language-specific and there is a single non-linguistic cognitive system, even though speakers group together conceptual features differently in accordance with the lexical semantic constraints of each language. The lexical items are part of the language system, but the concepts are not.

According to Paradis's Activation Threshold Hypothesis (1987b, 1993, 2004: 28-31), a linguistic item stored in a bilingual's brain requires, at any one time, a certain amount of positive neural impulse to activate it, and this requirement is its activation threshold. Every time an item is activated, the threshold is lowered, but it rises again if the item is not activated for a while. Whenever one item is activated, all other possible alternative items are inhibited, that is, their activation thresholds are raised. For whole languages, the process is described as follows (2004: 115): 
When one language is selected for expression, the activation threshold of the other language is raised so as to avoid interference [...]. However, it is not raised so high that it could not be activated by an incoming verbal stimulus that impinges on the auditory sensory system and sends impulses to the corresponding representation [...] the unselected language is not totally inhibited. Its activation threshold is simply raised high enough to prevent self-activation, but not so high as to preclude comprehension.

Given that Paradis (2004: 133-138) aligns himself closely with the theory of Universal Grammar, and given that De Houwer's account of bilingual language acquisition is compatible with the same, we have a good measure of theoretical consistency and coherence across the three areas so far investigated, and, as we shall see in a moment, also with the theory of Natural Translation.

\section{Natural Translation, Linguistic Competence and what remains to be explained}

The theories discussed above are clearly compatible with Harris and Sherwood's (1978) notion of Natural Translation developing from a pretranslation stage which exploits links established between sets of items in the two languages as they are acquired. The existence of that stage would provide a strong basis for the further development of a childhood bilingual's translation skills (for a recent account of these, see Valdés 2003). But as Toury (1995: 245-6) points out, Harris and Sherwood's model cannot account for non-native bilinguals' abilities to translate; nor can any of the models discussed account for the well documented fact of development through formal instruction of translating and interpreting skills.

Interestingly, Paradis's account of the prevention of interference by means of suppression of one of a bilingual's languages says little about what happens during actual translation or, particularly, interpreting, when what is obviously required is a balance between inhibition and activation: As Toury stresses (e.g. 1995: 274-279), ST interference is a sine qua non for adequacy in translation, but it has to be controlled to the extent that acceptability can also be achieved. We may hypothesize that, at least in successful simultaneous interpreting, the switch between inhibition and activation is facilitated by the regular use of the two languages together to verbalize similar concepts, which causes the differences in activation thresholds for the respective lexicalizations of the concepts in the two languages to remain relatively minor.

Translation, and perhaps also consecutive interpreting are likely to be different from simultaneous interpreting when it comes to the involvement of pre-established 
links between expressions in the two languages, on the one hand, and components of verbal communication that are beyond the subliminal, on the other. The latter components include sensory perception and feelings, episodic memory and encyclopaedic knowledge, metalinguistic knowledge and the pragmatics of the languages involved (Paradis 2004: 227). Translating, especially, often involves drafting, redrafting and editing, that is, highly conscious problem-solving activities, and neither Paradis nor Harris and Sherwood (1978) have much to say about how these phenomena impact on translating ability.

Three of the four features that Harris and Sherwood deduce for the bilingual, translating child over and above its natural predisposition to acquire language (see above) - a bilingual mental lexicon, a language-independent semantic store and an ability to conserve meaning across languages - are accounted for within currently preferred theories of Linguistic Competence and the Neurolinguistics of Bilingualism, neither of which draws qualitative or categorical distinctions between mono- and multi-lingualism. These theories are also compatible with De Houwer's view of bilingual language acquisition.

What remains to be dealt with in terms of performance from the Harris and Sherwood study are, then, (i) the pleasure that young children, as well as older translators, derive from the activity; (ii) non-native bilinguals' abilities to translate; and (iii) development through formal instruction of translating and interpreting skills. As far as I am aware, little has been written in the Translation Studies literature about (i) above, although I have experienced plenty of anecdotal evidence that the pleasure principle is widespread among translators. Below, I shall suggest a starting point for subsuming it within the field of translation pedagogy. The second and third points above are much more frequently discussed in formal settings under the heading of Translation Competence. But given the fact that they are obviously factors beyond Competence as an underlying basis for performance, it might be preferable to cease using the term. Until it is practically possible to do so, I shall enclose the term in double quotation marks.

\section{Translation Competence as an end state}

As Toury $(1980,1984)$ points out, attempts to clarify how Translation Competence can be achieved tend to emphasize the qualities a translator needs, with relatively little 
regard to what a potential translator sets out with or to the gradual development they may go through, for instance in a program of translator education and training. Thus, according to Shreve (2002: 154) the term "translation competence" "has come to represent a motley set of academic understandings about what one has to know (and by implication what one has to learn or be taught) to become a translator." In his entertaining, if somewhat acerbic article, Pym (2003) divides this motley set into four main types, as follows (I present only a selection of the numerous examples Pym cites), before producing a definition of his own:

\section{Summation of linguistic competencies}

According to Wilss (1982: 118; see Pym 2003: 483), Translation Competence amounts to source-language text-analytical ability together with target-language textreproductive ability. According to Koller (1979: 40; see Pym 2003: 483), it consists in "the ability to put together [verbinden] the linguistic competencies gained in two languages".

\section{No such thing as "competence"}

Pym (2003: 484) cites several studies by Wilss in which Translation Competence is reduced to other notions such as declarative knowledge and knowledge of translation processes (Wilss 1988), or proficiency (Wilss 1992), or code-switching (Wilss 1996). He also mentions Lörscher's (1991) reduction of Translation Competence to problemsolving strategies, and he takes Schäffner and Adab (2000: x) to task for slipping into an "almost unthinking reduction" (Pym 2003: 485) of competence to performance in their definition of competence as "a cover term and summative concept for the overall performance ability which seems so difficult to define" (Schäffner and Adab 2000: x).

\section{Multicomponentiality}

Under this heading, Pym (2003: 485) cites Bell's (1991) listing of components such as

target-language knowledge, text-type knowledge, source-language knowledge, subject area ("real-world") knowledge, contrastive knowledge [...] "communicative competence" (covering grammar, sociolinguistics and discourse). Virtually everything that any kind of linguistics wanted to talk about was tossed into the soup 
as Pym puts it. Also included are Hatim and Mason's (1997: 204-206) source-text processing, transfer, and target-text processing, with several skills under each heading, and Hewson's (1995: 108) additional "cultural and professional elements", including, under professional elements, "remuneration [...] access to and use of proper dictionaries and data banks, access to equivalent material in the second language, practical knowledge of word-processors and peripherals, and so on". Hurtado (1996, 1999) also appears here, as does Mayoral (2001: 109), who includes (see Pym 2003: 486) "common sense (above all), curiosity, ability to communicate, capacity for self-criticism, meticulousness, ability to synthesize, etc.”, and Robinson (1997) who adds "good typing speeds, Internet discussion groups, and working with a computer in a room at the right temperature".

\section{Just one thing}

Under this heading Pym (2003: 487) lists Toury's (1984, 1986) “transfer competence", which requires particular modes of socialization (cf. Toury 1995: 246, 250; to be discussed below), and Koller's (1992: 20; Pym 2003: 488) "creativity involved in finding and selecting between equivalents, and in the increasingly necessary [skills of] text production".

\section{Pym's own minimalist definition}

Pym's own view is that Translation Competence consists of two skills (2003: 489), "The ability to generate a series of more than one viable target text (TT1, $\mathrm{TT}_{2} \ldots \mathrm{TT}_{n}$ ) for a pertinent source text (ST)" and "The ability to select only one viable TT from this series, quickly and with justified confidence." He defends this position by pointing out (2003: 492-494) that (i) it allows for a clear distinction between translator training and language learning; (ii) it "sees translating as a process of producing and selecting between hypotheses" and that it is therefore "a mode of constant theorizing"; (iii) it "challenges the authoritarian role ...[of] the teacher of translation"; and, finally and importantly, (iv) it "can sustain a critical approach to those tasks and technologies that $[\ldots]$ mistake means for ends":

For instance, the postmodern abundance of information makes the production of alternative

TTs easy, which means that more emphasis has to be placed on the elimination of possible TTs

[...]. On the other hand, the use of translation memories facilitates the unthinking repetition of 
previous TTs, such that what is lacking in such modes of work is the active production of hypotheses [...]. More important, the use of websites, memories and the rest [...] invite[s] us to forget that our basic tasks involve communication between humans, and only then the manipulation of electronic mediation.

True and important though this may be, Pym's model is still of the desirable end state of Translation Competence; it has little to say about the aspiring translator's starting point and journey, issues to which I now turn.

\section{The development of Translation Competence}

In order to elucidate what the aspiring translator brings to the learning process, Toury (1984: 189) proposes that "the ability to translate presupposes the existence of two other, more basic abilities, namely (a) to acquire more than one language, and (b) to establish similarities and differences, on more than one level, between items and structures, if not full utterances, pertinent to the languages that one has actually acquired".

Toury classes both of these abilities as "humanly innate" (1984: 189). The ability to acquire more than one language is accounted for, as we have seen, by the language faculty, and it leads to what Toury refers to as "bilingual competence" which, as was made clear above, can be identified with Linguistic Competence. The second, which Toury calls "interlingual competence", may arise from Harris and Sherwood's pretranslation stage in the case of people who have been raised bilingually, but not in the case of people who have learnt one of their languages as a second or foreign language, as very many translators do. We therefore need to develop an account of how interlingual "competence" can be learnt, and learnt interlingual "competence" cannot be Competence in the Chomskyan sense. In fact, even in the case of people who have grown up in two languages, we may need a learning account of the ability to produce informed comparisons between languages, since, in my experience at least, not every bilingual, although they may be able to tell you how to say $x$ in language B where it is appropriate to say $y$ in language $\mathrm{A}$, is able to pinpoint the similarities and differences between the expressions. Similarly, few native speakers, even though they can tell you whether or not a string is a well-formed sentence of their language, can tell you why they have made that judgement. To have these abilities is already to have moved beyond the Competence that every normal 
native speaker (mono- or bi-lingual) attains, and into performance. It would therefore be more appropriate to refer to this component of the translator's ability as "Interlingual Proficiency Potential".

Furthermore, as Toury continues, the presence of these two properties "does not in itself imply the ability to translate" (1984: 189). Translating ability requires the two properties together with a third, "transfer competence", which Toury (1984: 190) borrows from Wilss (1982: 81). This competence, too, may derive from pretranslation in childhood bilinguals, but, again, not in people who have learnt second and subsequent languages later in life; besides, not all bilinguals are equally adept at this transfer, so a learning account is generally required. Therefore I shall avoid the term "competence", and refer to this component as "Transfer Proficiency Potential".

Toury (1995: 248-2358) makes a number of suggestions for how these Formatted: Indent: First line: $1.1 \mathrm{~cm}$ potentials develop and how they can be encouraged to unfold into actuality in training. To begin with, since translation, along with other forms of text production, is communicative, it is interactional and subject to shaping through environmental feedback, which is closely related to the norms that govern translational behaviour in a given environment at a given time. During a person's socialization as a translator, whether during formal training or during more informally gained experience, these norms become internalised, and this may result in inhibition of the kind of creativity that is often required in translation, and which probably distinguishes the truly great translator from the (merely) very able.

Consider, as an illustration of this kind of inhibition, a selection of translators' means of dealing with the first line of the opening paragraph of Hans Christian Andersen's story Den grimme Alling (1844) (“The ugly duckling”) (Malmkjær 1999: 20-34). The paragraph reads as follows (my emphases):

Der var saa deiligt ude paa Landet; det var Sommer, Kornet stod guult, Havren grøn, Høet var reist i Stakke nede i de grønne Enge, og der gik Storken paa sine lange, røde Been og snakkede ægyptisk, for det sprog havde han lært af sin Moder. Rundtom Ager og Eng var der store Skove, og midt i Skovene dybe Søer; jo, der var rigtignok deiligt derude paa Landet! Midt i Solskinnet laae der en gammel Herregaard med dybe Canaler rundt om, og fra Muren og ned til Vandet voxte store Skræppeblade, der vare saa høie, at smaa Børn kunde staae opreiste under de største; der var ligesaa vildsomt derinde, som i den tykkeste Skov, og her laae en And paa sin Rede; hun skulde ruge sine smaa Ællinger ud, men nu var hun næsten kjed af det, fordi det varede saa længe ... 
This paragraph constitutes a typical beginning for a piece of realist literary writing. It begins with a passage of description of a place in the distance, vis-à-vis the narrating voice, as indicated by the use of $d e r$ "there" as a place-deictic location adverb, before switching to the use of the proximal place-deictic adverb her, "here", which takes the narrating voice to the place being described and which coincides with a closing in on a central place/character, the duck on her nest. The shift is powerfully reinforced by means of the use of the past tense form of the verb corresponding to "to be", var, together with the temporal adverb of the immediate present, $n u$ : effectively "now was", which presents as present the point of view of a character being told about in the past tense. The narrating voice locates itself in the same place as the duck, "here", and creates empathy with her (Lyons 1977: 677; Adamson 1994).

The suddenness of the switch from there to here is heightened in the Danish passage by the repeated use, often in theme position in clauses, of a dummy subject having the same form as the place deictic distal adverb, der. In the gloss translation into English below, these are retained in Danish to show the effect:

Der (det) was so lovely out in the country; it was summer, the corn stood yellow, the oats green, the hay was raised in stacks down in the green meadows and der walked the stork on his long, red legs and talked Egyptian, for that language had he learnt from his mother. Around field and meadow were $\operatorname{der}(0)$ large forests, and in the middle of the forests deep lakes; yes, $\operatorname{der}($ det $)$ was indeed lovely derude (0) in the country! In the middle of the sunshine lay $\operatorname{der}(0)$ an old manor house with deep canals around it, and from the wall and down to the water grew large dock-leaves which were so high that small children could stand upright under the largest; $\boldsymbol{d e r}($ det $)$ was just as wildsome derinde (0) as in the thickest forest, and $\underline{\boldsymbol{h e r}}$ lay a duck on her nest; she had to hatch her small ducklings out, but now was she nearly bored with it, because it took so long.

All of these could either have been left out of the passage altogether, or another term, det (it) could have been used in their place, as also indicated in the gloss translation with either det or $O$ in brackets after the term in question. The availability of alternatives together with the constant preference for der strongly suggests deliberate choice on the writer's part, and in my opinion this is motivated by the reinforcement of the deictic shift which the repetitions of the der-form creates, and especially its use as the very first word of the passage.

In English, the only possible choice of dummy subject in weather and atmosphere conditions is "it", "there" being restricted to existential or presentative 
sentences like "there is someone at the door", and this fact seems to have hoodwinked the translators into disregarding the desirability of reproducing the Source Text pattern using, for example, a sentence like "There was no end of loveliness out in the country side" (with thanks to Tim Johns) to begin the passage:

Anon:
$\begin{aligned} & \text { Corrin: } \\ & \text { Dulcken: }\end{aligned}$ It was glorious out in the country. It was summer.
Haugaard: $\quad$ It was so beautiful out in the country. It was summer.
Keigwin: $\quad$ Summertime! How lovely it was out in the country,
Kingsland: $\quad$ It was so lovely out in the country! It was summer:
Lewis:
Peulevé:
Spink:

Toury suggests a number of remedies to counteract the force of the norms that govern translational behavior:

(1) Do not specialize too soon (1984: 191-2; cf. 1995: 253): "the greater the variety of situations that a translator is put into, the greater the range and flexibility of his ability to perform, or adapt himself to changing norms is going to be ... On the other hand, specialization ... will probably tend to ... reduce the adaptability of the translator".

(2) Allow for feedback from a variety of sources, including (i) tutors who are nonconformists and (ii) fellow students (1995: 256-7)

(3) Analyze past and present translations "with an eye to determining how their makeup and/or the relationships obtaining between them and their respective sources are interconnected with their (intended or realized) positions in the target culture, and with no immediate evaluative purpose in mind" (1995: 257-258). This can be supplemented with attempts to "apply the governing principles as they emerge" in 
order to open "the students' eyes to the multiplicity of modes of translation, all of which may be legitimate, according to one set of norms or another".

To this advice, I would like to add a suggestion of my own. We should, in my opinion, make as much as we possibly can of Harris and Sherwood's notion of translation enjoyment (see above), because, if nurtured and understood in a certain way, it will promote self-confident normativity, free of concerns for sanctions - a similar facility as the one that Toury (1995: 253-4) ascribes only to socioculturally acknowledged, high-status translators.

\section{Translation and enjoyment}

To prevent habitual associations from getting in the way of creativity, it seems to me that it would be helpful to train prospective translators to adopt an attitude to the language of texts which Scruton (1974, Ch 10) calls "the aesthetic attitude., and which he, interestingly, holds to have "a permanent tendency" to become normative to various degrees, because (1974: 139):

A normative attitude seeks to found agreement in reason, and not in some chance convergence of opinion. A man with a normative attitude to $X$ feels that others should recognize the qualities that he likes or admires in $X$, and on this basis come to like $X$ themselves.

Aesthetic judgements do not, however, imply sanctions, as the theory of translation norms suggests that norms do, and which moral judgements also tend to do (Scruton 1974: 141-2), so "we are no longer concerned with the enforcement of a code of conduct, but rather with the development of a capacity for enjoyment ... of an object for its own sake" (1974: 143). And (1974: 148): "If I am interested in $X$ for its own sake, then I shall respond to the question 'Why are you interested in $X$ ?' with the expression of the thought that provides the reason for my continued interest - in other words, I shall respond with a description of $X$ ".

This notion is clearly in harmony with Descriptive Translation Studies, but it also connects with the bilingual child's enjoyment of the repeated citation of its word pairs, because repetition is a kind of description of a linguistic object. A childhood bilingual will in all probability come to the translation programme with a predisposition to enjoy textual objects and to enjoy translating them. By engaging in 
some form of translational stylistics (see Malmkjær 2003, 2004) we can probably ensure that this type of enjoyment can be maintained for the childhood bilingual and fostered in translators whose additional languages are learnt later in life.

\author{
Notes \\ 1. The strong sense, currently, is Chomsky's sense of Universal Grammar as the initial state of the \\ language faculty, containing principles, parameters and semantic primitives. \\ 2. Chomsky would obviously not deny that language is in fact used for communication; he merely \\ insists that this is no more its primary purpose than speaking is the primary purpose of the mouth and \\ human breathing apparatus.
}

\title{
References
}

Adamson, Sylvia. 1994. "Subjectivity in Narration: Empathy and Echo". M. Yaguello. (ed.) Subjecthood and Subjectivity. Paris: Ophrys.

Austin, J. L. 1962. How To Do Things With Words Oxford: Oxford University Press.

Ahlsén, Elisabeth. 2006. Introduction to Neurolinguistics. Amsterdam and Philadelphia: Benjamins.

Bell, Roger T. 1991. Translation and Translating. Theory and Practice. London and New York: Longman.

Brown, Gillian. 1996. "Introduction". Gillian Brown, Kirsten Malmkjær and John Williams (eds) Performance and Competence in Second Language Acquisition. Cambridge: Cambridge University Press. 1-8.

Carr, P. 2006. "Philosophy of linguistics". Keith Brown (ed.) Encyclopedia of Language and Linguistics. Second Edition. Volume Nine. Amsterdam: Elsevier. 331-337.

Chomsky, Noam. 1965. Aspects of the Theory of Syntax. Cambridge, MA: MIT Press.

Chomsky, Noam. 2000. New Horizons in the Study of Language and Mind. Cambridge: Cambridge University Press.

De Houwer, A. 2006. "Bilingual language development: Early years". Keith Brown (ed.) Encyclopedia of Lanugage and Linguistics. Second Edition. Volume One. Amsterdam: Elsevier. 780-786.

Fabbro, Franco. 1999. Nuerolinguistics of Bilingualism. Hove: Psychology Press. 
Harris, Brian and Bianca Sherwood. 1978. "Translation as an Innate Skill”. David Gerver and H. Wallace Sinaiko (eds) Language, Interpretation and Communication. New York and London: Plenum. 155-170.

Hatim, Basil and Ian Mason. 1997. The Translator as Communicator. London and New York: Routledge.

Hewson, Lance. 1995. "Detecting Cultural Shifts: Some Notes on Translation Assessment". Ian Mason and Christine Pagnoulle (eds) Cross-Words. Issues and Debates in Literary and Non-Literary Translating. Liège: University of Liège.101-108.

Hurtado Albir, Amparo. 1996. "La enseñanza de la traducción directa 'general'. Objetivos de aprendizaje y metodología”. Amparo Hurtado Albir (ed.) La enseñanza de la traducción. Castelló: Publicacions de la Universitat Jaume I. 31-55.

Hymes, Dell. 1971. "Competence and performance in linguistic theory". R. Huxley and E. Ingram (eds) Language Acquisition: Models and Methods. New York: Academic Press.

Hymes, Dell. 1972a. "On communicative competence". J. B. Pride and J. Holmes (eds) Sociolinguistics Harmondsworth: Penguin. 269-286.

Hymes, Dell. 1972b. "Models of the interaction of language and social life". John Gumperz and Dell Hymes (eds) Directions in Sociolinguistics: The Ethnography of Communication. Oxford: Basil Blackwell. 35-71.

Koller, Werner. 1979. Einführung in die Übersetzungswissenschaft. Heidelberg: Quelle \& Meyer.

Koller, Werner. 1992. Einführung in die Übersetzungswissenschaft, Völlig neu bearbeitete Auflage. Heidelberg, Wiesbaden: Quelle \& Meyer.

Leopold, W. F. 1949. Speech Development of a Bilingual Child: A Linguist's Record. Evanston, Il: Northwestern University Press.

Lörscher, Wolfgang. 1991. Translation Performance, Translation Process, and Translation Strategies: A Psycholinguistic Investigation. Tübingen: Narr.

Lyons, John. 1996. "On competence and performance and related notions". Gillian Brown, Kirsten Malmkjær and John Williams (eds) Performance and Competence in Second Language Acquisition. Cambridge: Cambridge University Press. 11-32. 
Malmkjær, Kirsten. 1999. Descriptive Linguistics and Translation Studies: Interface and Difference. Platform Papers on Translation Studies 1. Utrecht: Platform Vertalen \& Vertaalwetenschap

Malmkjær, Kirsten. 2003 "What happened to God and the angels: An Exercise in Translational Stylistics". Target 15(1): 39-62.

Malmkjær, Kirsten. 2004. “Translational Stylistics”. Language and Literature 13(1): 13-24.

Malmkjær, Kirsten, forthcoming, spring 2007 "Norms and nature in translation studies". Gunilla Anderman and Margaret Rogers (eds) Incorporating Corpora - Corpora and the Translator. Clevedon: Multilingual Matters.

Mayoral, Roberto. 2001. Aspectos epistemológicos de la traducción. Castelló: Publicacions de la Universitat Jaume I.

Paradis, Michel. 1985. "On the representation of two languages in one brain". Language Sciences 7: 1-39.

Paradis, Michel. 1987a. "Le bilinguisme". J. Rondal and J.-P. Thibaut (eds.) Problèmes de psycholinguistique. Brussels: Mardaga. 421-489.

Paradis, Michel. 1987b. "Neurolinguistic perspectives on bilingualism". Michel Paradis and G. Lippen. The Assessment of Bilingual Aphasia. Hillsdale, NJ: Lawrence Erlbaum. 1-17.

Paradis, Michel. 1993. "Linguistic, psycholinguistic and neurolinguistic aspects of "interference" in bilingual speakers: The Activated Threshold Hypothesis". International Journal of Psycholinguistics 9: 133-145.

Paradis, Michel. 2004. A Neurolinguistic Theory of Bilingualism. Amsterdam and Philadelphia: Benjamins.

Pym, Anthony. 2003. "Redefining translation competence in an electronic age. In defence of a minimalist approach". Meta 48(4): 481-497.

Radford, Andrew 2004. English Syntax: An Introduction. Cambridge: Cambridge University Press.

Robinson, Douglas. 1997. Becoming a Translator: An Accelerated Course. London and New York: Routledge.

Ronjat, J. 1913. Le développement du langage observe chez un enfant bilingue. Paris Champion.

Saussure, Ferdinand de. 1916/1959. Course in General Linguistics. Ed. C. Bally and A. Sechehaye, trans. Wade Baskin. New York: McGraw Hill. 
Schäffner, Christina and Beverly Adab. 2000. "Developing Translation Competence: Introduction". Christina Schäffner and Beverly Adab (eds) Developing Translation Competence. Amsterdam and Philadelphia: Benjamins. vii-xvi.

Scruton, Roger. 1974. Art and Imagination: A Study in the Philosophy of Mind. London: Methuen.

Shreve, Gregory M. 2002. "Knowing translation: Cognitive and experiential aspects of translation expertise from the perspective of expertise studies". Alessandra Riccardi (ed) Translation Studies: Perspectives on an Emerging Discipline. Cambridge: Cambridge University Press. 150-171.

Tirkkonen-Condit, Sonja. 2004. "Unique items - over- or under-represented in translated language?". Anna Mauranen and Pekka Kujamäki (eds) Translation Universals - Do They Exist? Amsterdam and Philadelphia: Benjamins. 177184.

Toury, Gideon. 1980. "The translator as a nonconformist-to-be, or: How to train translators so as to violate translational norms". Sven-Olaf Poulsen and Wolfram Wilss (eds) Angewandte Übersetzungswissenschaft. Århus. 180-194.

Toury, Gideon. 1984. "The notion of 'Native Translator' and translation teaching". Wolfram Wilss and Gisela Thome (eds) Die Theorie des Übersetzens und ihr Aufschlußwert für die Übersetzungs- und Dolmetschdidaktik. Tübingen: Narr. 186-195.

Toury Gideon. 1995. Descriptive Translation Studies and beyond. Amsterdam and Philadelphia: Benjamins.

Valdés, Guadalupe. 2003. Expanding Definitions of Giftedness: The Case of Young Interpreters from Immigrant Communities. Mahwah, NJ and London: Lawrence Erlbaum. 25-61.

Wearing, C. 2006. "Philosophy of science and linguistics". Keith Brown (ed.) Encyclopedia of Language and Linguistics. Second Edition. Volume Nine. Amsterdam: Elsevier. 340-343.

Wilss, Wolfram. 1976. "Perspectives and Limitations of a Didactic Framework for the Teaching of Translation". Richard W. Brislin (ed.) Translation. Applications and Research. New York: Gardner Press. 117-137.

Wilss, Wolfram. 1982. The Science of Translation. Problems and Methods. Tübingen: Narr.

Wilss, Wolfram. 1988. Kognition und Übersetzen. Tübingen: Niemeyer. 
Wilss, Wolfram. 1992. Übersetzungsfertigkeit, Annäherungen an einen komplexen übersetzungspraktischen Begriff Tübingen: Narr.

Wilss, Wolfram. 1996. Übersetzungsunterricht. Eine Einführung. Tübingen: Narr.

\section{Source for Andersen's original text}

H.C. Andersens Eventyr: Kritisk udgivet efter de originale Eventyrhafter med Varianter ved Erik Dal og Kommentar ved Erling Nielsen. 1963-1966. Copenhagen: Hans Reitzels Forlag.

\section{Sources for the translations}

Hans Christian Andersen: Fairy Tales. Translator not named. London etc.: Hamlyn. 1959.

Tales from Hans Andersen. Translated by Stephen Corrin 1978. London: Guild Publishing. 1989.

The Complete Illustrated Stories of Hans Christian Andersen. Translated by H.W.

Dulcken. First published 1866. Reissued in 1983 and 1994, London: Chancellor Press.

Hans Andersen: His Classic Fairy Tales. Translation Copyright Erik Haugaard 1976. London: Lynx. 1988.

Hans Christian Andersen: Eighty Fairy Tales. Translated by R.P. Keigwin.

Odense: Skandinavisk Bogforlag. 1976. With an introduction by Elias

Bredsdorff. New York: Pantheon Books. 1982.

Hans Andersen's Fairy Tales: A Selection. Translated from the Danish by L.W.

Kingsland. London: Oxford University Press. 1959.

Hans Andersen's Fairy Tales. Translated by Naomi Lewis. London: Puffin Books. 1981.

Hans Christian Andersen: Fairy Tales. Translated by Marie-Louise Peulevé.

Odense: Skandinavisk Bogforlag. No Date (but pre-1968).

Hans Christian Andersen: Fairy Tales. Translated by Reginald Spink. London: David Campbell Publishers Ltd, 1992 (translation copyright Spink 1960).

The Stories of Hans Christian Andersen: A new Translation from the Danish. Diana

Crone Frank and Jeffrey Frank. London: Granta Books. 2003.

Hans Christian Andersen: Fairy Tales. A new Translation. Tiina Nunnally.

Harmondsworth: Penguin Books 2004. 
